\title{
AreCorporate Social and Environmental Responsibility, Firm Performance and Value Mutually Exclusive? Evidence from Egypt
}

\section{Dr. Ahmed Hassan Ahmed}

\begin{abstract}
The absence of any consensus regarding the economic implications of social, environmental and governance (ESG) practices as well as the introduction of a new index in Egypt with regard to ESG activities provides the initial impetus for the current paper. The purpose of the current study is to examine the association between ESG performance, financial performance and firm valueafter taking account of control variablesusing data for a sample of Egyptian listed firms. The sample consists ofall companies listed on the Egyptian Exchange (EGX). Univariate and multivariate analyses have been employed to examine the impact of ESG activities on firm performance and firm value. The results of the multivariate analysis were consistentwith the findings of the univariate analysis, which reported a significant positive association between ESG and firm value, while a negative association was revealed concerning firm performance, but no statistical significance was resulted. With respect to control variables, the findings revealed a positive association concerning company size and leverage, while a negative relationship was reported in the case of growth and liquidity. The results of the current study highlighted the impact ofESG on firm's financial performance, which in turn could affect company's decision whether or not to engage in ESG practices. The findings have implications for regulators and standards setters tasked with developing accounting standards to control ESG practices in a developing country, such as Egypt.
\end{abstract}

Keywords: CSR; firm value; financial performance; Egypt

Contact Details:

Faculty of Commerce,

South Valley University, Email: a.h.ahmed@svu.edu.eg, Tel: 01021222388 


\section{Introduction}

McWilliams and Siegel (2001) suggest that corporate social responsibility (CSR) revolves around "actions that appear to further some social good, beyond the interest of the firm and that which is required by law" (p. 117). In recent years, there has been a growing demand among some customers, employees, communities, governments and shareholders for companies to adopt policies regarding social and environmental issues (McWilliams and Siegel, 2000).At the same time, global investments managed according to social and environmentally responsible principles have expanded dramatically, rising from $\$ 13.3$ trillion in 2012to \$21.4 trillion in 2014 (Global Sustainable Investment Alliance, 2014).Not surprisingly, therefore, various attempts have been made to investigate the economic implications of CSR practices; however the results, to date, have not been conclusive (Cochranand Wood, 1984; McGuire et al., 1988; Clarkson et al., 2011). Such inconclusiveness has led to calls for further research in this area (Mishra and Suar, $2010)^{1}$.One strand of research into the link between CSR and firm performance suggests that corporations will face a trade-off between the costs of adopting additional social, environmental and governance polices and the benefits from improved financial performance (McGuire et al., 1988). Proponents of this view argue that firms have to undertake newinvestments in such activities and therefore incur extra costs which can potentially reduce market value(Cochran and Wood, 1984; McGuire et al., 1988; Barnea and Rubin, 2010). Examples of socially and environmentally responsible activities include investments to reduce pollution and charity work.Managers may also oppose the introduction of such practices, arguing that these extra costs conflict with their endeavours to maximise shareholders' wealth (McWilliams and Siegel, 2000) and may reduce any due bonuses based on firm performance.

\footnotetext{
${ }^{1}$ Indeed, it has been argued that the absence of any agreement over a link between social, environmental and governance practices and financial performance measures, may discourage firms from engaging in such practices (British Council et al., 2002).
} 
Another strand of researchin this area argues that firms should play a positive role in communities in which they operate as wealth maximisation should not be the sole objective of companies (Tsoutsoura, 2004).In this context, Clarkson et al., (2011) argued that engaging in CSR activities involves costs which may be offset by benefits to a wide group of stakeholders. Similarly, Hansen and Mowen (2007) have argued that "meeting sound business objectives and resolving environmental concerns are not mutually exclusive" (p. 778). Even shareholders may gain from a firm's CSR activities if any expenditures linked with these activities are associated with a reduction in the company's risk. For example, Clarkson et al. (2011) indicated that "it does indeed pay to be green if firms are willing to make significant changes in their environmental strategy... [as] good environmental performance reduces regulatory risk, [and] hence, directly affects valuation through a lower discount rate" (p. 125). As a result, investors may place a premium on firms with environmental policies and penalise those which do not adopt CSR (Klassen and McLaughlin, 1996).Therefore, if managed effectively, CSR will not only improve the satisfaction of interested parties ${ }^{2}$ but also enhance company's performance (Hansen and Mowen, 2007). Consequently, disclosures of CSR practices has grown exponentially in the last two decades, as more companies have become aware of their social and environmental responsibilities that go beyond those expressed in financial terms and, for some, increasingly recognising the value of a more holistic reporting system to performance (OECD, 2014).

Although a sizeable body of literature exists on the link between CSR and firm performance and firm value, not many of these studiesundertaken in developing countries, including Egypt. All CSR studies undertaken in Egypt to date have either sought to determine the extent of CSR practices amongst companies listed on the EGX and/or exploring the factors that affect

${ }^{2}$ For example, satisfied customers will be more loyal to the company and satisfied employees will be more willing to work effectively. 
companies decisions to engage in such practices and explain the variations of these practices amongst the sample companies (e.g. Hanafi, 2006; Rizk et al., 2008; Salama, 2009; Elmaghrabi, 2010 and Hussainey et al., 2011); no studies have sought to explore the economic consequences of CSR practices.Thus, the present study addresses a specific gap in the literature by examining the association between CSR and firm value; to the best of our knowledge, this is the first study to investigate the association between CSR, firm performance and value. This matters in an Egyptian setting as the nation's economy is the second largest in the Middle Eastern and North Africa region.

The main purpose of the current paper is to examine the association between corporate social responsibility (CSR) and firm value and financial performance using data for a sample of Egyptian firms listed on the EGX.In particular, it investigates the relationship between the CSR practices of the sampled companies- as determined by the Egyptian Corporate Responsibility Index (S\&P/EGX ESG Index)- and theirfirm value and financial performance. Specifically, it examines whetheror not firms are rewarded for being socially and environmentally responsible with a better firm value and performance. The S\&P/EGX $\mathrm{ESG}^{3}$ Index was launched by the EGX in March 2010 and aims at enhancing the transparency and disclosure practices of listed companies with regard to corporate governance and CSR practices, and is the first of its kind to be launched in the Middle East (EGX, 2010). This index includes 30 companies listed on the EGX and is subject to annual review. In this context, it has been argued that ESG reporting is considered to be a mechanism that governments use to keep stakeholders more informed about big companies and to ensure that these companies are operating responsibly (OECD, 2014).

\footnotetext{
${ }^{3}$ ESG disclosures emerged as part of corporate social responsibility on a voluntary basis, as a means for companies to present their activities beyond the mandatory requirements (OECD, 2014).
} 
The absence of any specific link between CSR practices and performance measures may discourage firms from engaging in such practices.In this context, the OECD $(2014$, p. 6) asserted that "transparency and comparability of corporate performance in ESG must become the topic of policy-making: it is not a luxury that only financially wealthy companies indulge in - good practice in this areashould be rewarded and become a distinctive feature for investors".Therefore, the results reported in this study may encourage more firmsto implement CSR practices. Furthermore, the current study provides up-to-date evidence concerning the economic consequences of CSR practices. The results presented in this paper should therefore be of interest to regulators and standard-setters charged with developing regulations to control CSR practices, as these practices are still voluntary in nature with firms having discretion over what, how and when to disclose such information.

The remainder of this paper is organised as follows. Section 2 reviews the extant literature in the area and state research hypotheses, while details about the research methodology and data collection process are presented in Section 3. The results are reported in Section 4. Finally, Section 5concludes the paper by summarising the findingsof the existing research and identifying future avenues to explore.

\section{Literature Review and Hypothesis Formulation}

The extant literature has not reported conclusive results regarding the economic implications of CSR disclosures. For example, Margolis et al. (2009) provide a review of 251 studies that have examined the association between engaging in CSR practices and financial performance. They revealed a small positive relationship between CSR and financial performance.In this regard, McWilliams and Siegel (2000) examined the impact of CSR on financial performance 
for a sample of 524 firms drawn from Kinder, Lydenberg, Domini (KLD) ${ }^{4}$ ratings over the period 1991-1996. The evidence reported that CSR and profitability seems to be strongly positively associated. Similarly, Tsoutsoura (2004) investigated the association between CSR and financial performance using a sample of the S\&P 500 during the period 1996-2000. The results show that CSR is significantly positively associated with financial performance, supporting the view that socially responsible practices could be linked to a series of bottomline benefits. Furthermore, Salama (2005) reported a positive relationship between corporate environmental performance and financial performance using median regression analysis for a sample of 201 British companies. In the Indian context, Mishra and Suar (2010) explored the link between CSR practices and profitability. The findings indicated that social responsible firms have better financial performance. Similarly, looking at a sample of 153 companies listed on the Stoxx Europe Sustainability Index between 2007 and 2010, Marti et al. (2013) found that the financial performance of the sample companies is associated with the extent of their sustainability practices over the investigated period.

Based on the preceding discussion, we argue that ESG, as determined by the Egyptian Corporate Responsibility Index, has a positive impact on firm performance. Therefore, this study proposes the following hypothesis:

H1: Environmental, social and governanceperformanceis positively associated with firm's financial performance.

Another strand of the CSR literature has examined the relationship between these practices and firm value. For instance, Jo and Harjoto (2011) reported a positive relationship between CSR engagement and firm value measure by industry adjusted Tobin's q.In the same vein,

\footnotetext{
${ }^{4} \mathrm{KLD}$ is a "social investment and screening firm whose evaluations are used widely within the financial services industry. KLD evaluates the membership of the S\&P 500 along a wide range of social performance indicators. Specifically KLD examines seven 'strength' and seven 'concern' environmental dimensions ranging from the extent to which the firm engages in pollution prevention programs or uses alternative fuels to the firm's use of ozone depleting chemicals or its generation of hazardous wastes (Sharfman and Fernando, 2008, p. 578).
} 
Clarkson et al. (2013) investigate the association between voluntary disclosure of environmental information and firm value using a US sample. They reported that such disclosures provide valuation relevant information. In addition, Servaes and Tamayo (2013) explored the influence of CSR practices on firm value for a sample of companies covered by KLD States database over the period 1991-2005. The study reported a positive association between CSR and firm value. Matsumura et al. (2013) examined the association between carbon emissions and firm value and they found that every thousand metric tons of carbon emissions resulted in $\$ 212,000$ reduction in firm value. Furthermore, they indicated that reduction in firm value for carbon emissions non-disclosing firms was more than that of disclosing firms. Similarly, a recent study by Gregory et al. (2014), found that markets positively value CSR practices.In a more recent study, Plumlee et al. (2015) examine the association between the quality of voluntary environmental disclosure and the components of firm value (expected future cash flows and cost of equity capital) using data for 474 US firms representing five industries over a six-year period (2000-2005). Environmental disclosure was measured using a disclosure index comprising 351 points and is consistent with the Global Reporting Initiative (GRI, 2006) disclosure framework. The results show that voluntary environmental disclosures are significantly positively associated with firm value through both the cash flow and cost of equity capital components.Based on the preceding discussion, we argue that CSR, as determined by the Egyptian Corporate Responsibility Index, has a positive impact on firm value as measured by Tobin's q. Therefore, this study proposes the following hypothesis:

H2: Environmental, social and governance performance is positively associated with firm value.

The current paper contributes to the two strands of the literature by examining the associationbetween ESG, firm performance and firm value for the emerging economy of 
Egypt. All CSR studiesundertaken in Egypt to date have either sought to determine the extent of CSR practices amongst companies listed on the EGX and/or exploring the factors that affect companies decisions to engage in such practices and explain the variations of these practices amongst the sample companies (e.g. Hanafi, 2006; Rizk et al., 2008; Salama, 2009; Elmaghrabi, 2010 and Hussainey et al., 2011); no studieshave sought to explore the economic consequences of CSR practices. Thus, the present studyaddresses a specific gap in the literature by examining the association between ESG, firm performance and firmvalue. To the best of the researcher knowledge, this is the first study to investigate the associationbetween ESG, firm performance and firmvalue. This matters in an Egyptian setting as the nation has a major influence on other countries in the Middle Eastern and North Africa region as well its traditionally strong historical relationships with the world's richest nations (Ahmed, 2013).

\section{Sample Selection and Method}

The sample encompassesall of the 224 companies listed on the EGX in 2014. After deleting firms with missing data, our final sample includes 130firms listed on the Egyptian Exchange. Data with regard to ESG performance were collected via the Egyptian Institute of Directors and Egyptian Exchange websites, whilethe Thomson Reuters DataStream database was used to obtain the dependant variables. As with the prior studies in this area, the outliers of all variables are winsorised to the 5 and 95 percentiles (Francis et al., 2005).

Comincioli et al. (2012) have argued that "CSR is not a variable and therefore it is not measurable" (p. 2). However, several studies have developed proxies to measure CSR. But these past studies have been challenged on the grounds that the measures of CSR that they use are unreliable (Mishra and Suar, 2010; Clarkson et al., 2011). This problem has been tackled in the literature by using two different CSR measures. The first is a reputation index, in which 
professional observers and specialised rating agencies give specific ranking for firms based on one or more aspects of CSR (Cochran and Wood, 1984), the most common indices include KLD as mentioned previously. The second common method of measuring CSR involves a content analysis, in which CSR is measured by determining the extent of CSR practices reported in various publications including annual reports and corporate websites (Cochran and Wood, 1984; Servaes and Tamayo, 2013). One obvious drawback of the content analysis approach is that "it is only an indication of what firms say they are doing, and this may be very different from what they are actually doing" (Cochran and Wood, 1984, p. 44).In contrast, the reputation index does not suffer from this limitation,therefore acknowledging this advantage, the present study will rely on the reputation index for determining the extent of ESG practices amongst companies listed on the EGX.

The Environment, Social and Governance (ESG) Indexfor Egyptian listed companies was constructed by the Egyptian Institute of Directors (EIoD), Egyptian Corporate Responsibility Centre (ECRC)and Standard\& Poor's (S\&P) and is employed as a proxy to determinethe extent of ESGamongst companies listed on the EGX in the present study. To develop this index,S\&P and the EGX use nine criteria namely: ownership structure and shareholder rights, financial and operational information, board and management structure and process, corporate governance \& corruption, business ethics and corporate responsibility, environment, employees, community, and customers/product. To arrive at the total score for each of the sampled companies, two scores have to be calculated for each company namely: (i) Quantitative Score -in which each of the companies listed on the EGX is assigned a quantitative ranking based on the three factors; transparency and disclosure of (1) corporate governance, (2) environmental practices, and (3) social practices, and (ii) Qualitative Score in which independent sources of information (i.e. news stories, websites and CSR filings) are 
used to evaluate the actual performance of the company on a scale of 5 to 1.Finally, the total score is calculated for each company by summing the qualitative score and the quantitative score.These scores were then ranked across all companies listed on the EGX and the first 30 companies constitute the S\&P/EGX ESG Index.

To test hypothesis 1 , the following regression is estimated:

Firm Performance $(R O A)=\partial_{0}+\partial_{1} E S G_{c, t}+\partial_{2}$ Growth $_{c, t}+\partial_{3}$ Leverage $_{c, t}+\partial_{4}$ Size $_{c, t}+$ d5Liquidityc, $t+\delta c[1]$

Where: ESG is the environmental, social and governance performance as shown in the S\&P/EGX ESG Index.ESG is a dummy variable taking the value of 1 if the company is a constituent in the S\&P/EGX ESG Index, 0 otherwise.Financial performance of the sample companies was measured using return on assets, which is consistently claimed to be an authentic measure of financial performance (Salama, 2005).

To test hypothesis 2 , the following regression is estimated:

Firm Value $\left(\right.$ Tobin' $\left.^{\prime} Q\right)=\partial_{0}+\partial_{1} E_{S G} G_{c, t}+\partial_{2}$ Growth $_{c, t}+\partial_{3}$ Leverage $_{c, t}+\partial_{4}$ Size $_{c, t}+$ d5Liquidityc, $t+\delta c[2]$

We measured firm value using Tobin's Q, which has been adopted widely in accounting, economics and finance studies (Jo and Harjoto, 2011). Tobin's Qis calculated as \{[Book value of assets - Book value of equity + Market value of equity/Book value of assets $\}$ ]. Furthermore, we use industry-adjusted Tobin's q ${ }^{5}$. Size is log of a firm's market value in year $\mathrm{t}$; Growth is the log of one plus the firm's growth in book value of equity;Leverage is a firm's

\footnotetext{
${ }^{5}$ It is calculated as: the natural log of firm's Tobin's q/the Median of Tobin's q in the firm's industry.
} 
interest-bearing debt deflated by total assets in year $\mathrm{t}$, and liquidity is the current ratio in year t. Table 1 provides a description for all the variables included in the current analysis.

Table 1: Description of the Variables Included in the Analysis

\begin{tabular}{|c|c|}
\hline Variable & Description \\
\hline ESG & $\begin{array}{l}\text { A dummy variable taking the value of } 1 \text { if the company are a } \\
\text { constituent in the S\&P/EGX ESG Index, } 0 \text { otherwise }\end{array}$ \\
\hline ROA & Return on assets at December 31,2014 \\
\hline Tobin'sq & $\begin{array}{l}\{[\text { Book value of assets }- \text { Book value of equity }+ \text { Market value of } \\
\text { equity/Book value of assets }\}]\end{array}$ \\
\hline Size & Log of market value at December 31, 2014 \\
\hline Growth & $\begin{array}{l}\text { Log of one plus the firm's growth in book value of equityat } \\
\text { December } 31,2014\end{array}$ \\
\hline Leverage & $\begin{array}{l}\text { The ratio of total liabilities to total owners' equity at December } 31 \text {, } \\
2014\end{array}$ \\
\hline Liquidity & The Current ratio at December 31, 2014 \\
\hline
\end{tabular}

Note: This table provides a description of each of the different variables included in the current analysis.

According to the literature, we would expect the co-efficient on the ROA variable to be positive, indicating that companies acting responsibly in terms of their ESG activities are rewarded with better financial performance. Furthermore, in line with the extant literature that examines the link between ESG and firm value, we would again expect the co-efficient on Tobin's Q to be positive, implying again that being socially and environmentally responsible can be rewarded by improving firm value. For control variables, the literature suggests that the coefficients for firm growth, size and liquidity should be positive since large and solvent firms with high growth can typicallyafford to engage in ESG activities. By contrast, we expect negative coefficients with respect to leverage, as firms with a lot of debt will be expected to be reluctant to incur additional costs by engaging in ESG activities.

\section{Empirical Tests and Results}

\subsection{Descriptive Statistics}

Table 2 reports the descriptive statistics regarding the ESG, firm performance (ROA), firm value (Tobin's Q), and firm characteristics for the sample companies. The ESGindex has 
mean of 0.13 , as can be seen from Table 2.In addition, the mean value for the ROA is 5.3, while the median is 4.7 and the standard deviation amounted to be 7.4 implying that the sample companies varies in terms of their return on assets. With respect to descriptive statistics concerning firm value, which is measured using Tobin's Q, Table 2 shows that the mean value of Tobin's $\mathrm{Q}$ is 1.3, while the mean value for median Tobin's $\mathrm{Q}$ is 1.234, implying that there is no significant difference between firm value within each of the sample companies and the value in the industry. This result could be linked to the fact that companies belonging to the same industry tend to have similar characteristics. Moreover, Table 2 reports summary information for the control variables examined in the present study. The typical firm in the sample had total assets of about $£ 2,700$ million. The sample companies mean level of equity growth was about 7.7 and it had a mean level of leverage of 15.41 , while the mean value for liquidity amounted to be 5.17 with a standard deviation of 18.12 implying that the sample companies have varying levels of solvency.

Table 2: Descriptive Statistics on ESG, Firm Performance, Tobin's Q, and Control Variables

\begin{tabular}{|c|c|c|c|c|c|c|c|}
\hline Variables & Mean & STDV & Min & $25 \%$ & Med & $75 \%$ & Max \\
\hline ESG & 0.13 & 0.338 & 0 & 0 & 0 & 0 & 1 \\
\hline ROA & 5.330 & 6.293 & -7.350 & 1.530 & 5.300 & 8.280 & 20.36 \\
\hline Tobin'sQ & 1.303 & 0.449 & 0.697 & 0.995 & 1.283 & 1.437 & 2.475 \\
\hline Median Tobin'sQ & 1.243 & 0.139 & 0.404 & 1.209 & 1.308 & 1.341 & 1.454 \\
\hline Equity Growth & 7.773 & 20.00 & -21.05 & -3.030 & 1.790 & 16.16 & 65.21 \\
\hline Leverage & 15.41 & 15.26 & 0 & 1.080 & 15.85 & 20.81 & 53.67 \\
\hline Total Assets £mil & 2700 & 3600 & 80 & 280 & 1300 & 3600 & 14000 \\
\hline Size & 13.84 & 1.544 & 11.29 & 12.55 & 14.09 & 15.09 & 16.44 \\
\hline Liquidity & 5.174 & 18.12 & 0.0500 & 1.090 & 1.680 & 4.670 & 210.3 \\
\hline
\end{tabular}




\subsection{Univariate Analysis}

Table 3 reports the results concerning the correlations amongst ESG, ROA, Tobin's Q, and the control variables. The results show a negativebut not significant association between firm performance, measured by ROA, and ESG. Although this finding is considered an odd result which is not consistent with the extant literature linking CSR practices to firm performance, it is in line with the views which argue that firms encounter a trade-off between ESG practices and financial performance, as companies engaging in socially and environmentally responsibleactivities will incur further costs (McGuire et al., 1988). Furthermore, the results reveal that firm value, which is measured by Tobin'sq, has a positive association with ESG, but again no significance was resulted. This result can be linked to the idea that investors reward firms for being social and environmentally responsible, similar results were reported by Jo and Harjoto (2011). For the control variables, we find positive, but not significant association betweenESG and company size, implying that large companies have enough resources to fund ESG activities. Furthermore, Table 3 shows a positive but again not significant relationship between ESG and leverage. This result stresses the idea that creditors may put pressures on companies to engage in ESG activities. On the other hand, we find a negative correlation betweenESG, growth and liquidity,but in both cases the coefficients were not significant. These findings again can be linked to the idea that being socially and environmentally responsible involves extra costs which could eventuallyaffect firm's growth and solvency in a negative way especially in the short term ${ }^{6}$.The correlations among ESG and other variables range between -0.009 to0.41 which indicatesthat no multicollinearity problem is present among the independent variables ${ }^{7}$.

\footnotetext{
${ }^{6}$ The present analysis only covers one year, which is 2014. Benefits from engaging in ESG practices could be gained in the coming years.

${ }_{7}$ Variance Inflation Factors (VIFs) were also calculated to quantify the severity of any multicollinearity in subsequent regression analyses. VIFs above ten are thought to indicate severe multicollinearity problems. The
} 
Table 3: Pearson Correlation between ESG, Firm Performance, Firm Value and other Control Variables

\begin{tabular}{lllllllll}
\hline Variables & ESG & ROA & Tobin'sq & Mtobin'sq & Growth & Leverage & Size & Liquidity \\
\hline ESG & 1.000 & & & & & & & \\
ROA & -0.009 & 1.000 & & & & & & \\
& 0.904 & & & & & & & \\
Tobin'sq & 0.194 & 0.158 & 1.000 & & & & & \\
& 0.011 & 0.067 & & & & & & \\
Mtobin'sq & 0.195 & 0.077 & 0.317 & 1.000 & & & & \\
& 0.011 & 0.375 & 0.000 & & & & & \\
Growth & -0.009 & 0.254 & -0.065 & -0.214 & 1.000 & & & \\
& 0.915 & 0.003 & 0.642 & 0.809 & & & & \\
Leverage & 0.208 & -0.210 & -0.033 & 0.071 & -0.110 & 1.000 & & \\
& 0.006 & 0.006 & 0.673 & 0.361 & 0.216 & & & \\
Size & 0.411 & 0.105 & 0.023 & 0.094 & -0.054 & 0.253 & 1.000 & \\
& 0.000 & 0.176 & 0.770 & 0.226 & 0.544 & 0.001 & & \\
Liquidity & -0.074 & -0.167 & 0.022 & 0.142 & 0.215 & -0.177 & -0.21 & 1.000 \\
& 0.341 & 0.030 & 0.778 & 0.066 & 0.014 & 0.022 & 0.00 & \\
\hline
\end{tabular}

Note: The Table reports the correlations between ESG and other variables investigated in the present study.

\subsection{Multivariate Analysis}

In this section, we document the results for the main tests of the relationship between a firm's ESG performance, firm value and firm performance after taking account of control variables. The analysis employed return on assets to account for firm performance, while Tobin's Q and industry-adjusted Tobin's Qwere used as a measure for firm value.ESGdata were obtained from the EGX and EIoDwebsites, while control variables are collected from DataStream as mentioned previously. The control variables are growth, leverage, size and liquidity.

Table 4 provides both the mean of the yearly coefficients from estimating equations ( 1 and 2 ) and their statistical significance.Table 4 below shows a negative, but not significant, association between ESG and firm performance; the coefficient estimate is - 0.53 (t-statistic =0.24). This finding is consistent with the result obtained from the univariate analysis and led

results showed that none of the VIFs were above two, which suggests that multicollinearity does not pose a problem in the regression analyses. 
us to reject the first hypothesis (H1), which hypotheses a positive association between ESG and firm performance. Although this evidence is not in line with the extant literature linking ESG to firm performance (e.g., McWilliams and Siegel, 2000; Tsoutsoura, 2004; Salama, 2005; Mishara and Suar, 2010; Marti et al., 2013), it highlights the idea that socially and environmentally responsible firms incur additional costs for engaging in ESG activities which in turn might affect their financial performance in a negative way. On the other hand, the results reported in Table 4 showed a positive association between ESG and firm value which is significant $10 \%$ confidence level; the coefficient estimate is 0.24 (t-statistic $=1.81)$. This finding suggests that firms with higher quality ESGratings have value compared to their lower quality ESG counterparts. Again this result confirms those reported in the univariate analysis shown in Table 3, thus, there is support for the second hypothesis $\left(\mathrm{H}_{2}\right)$, which postulates a positive association between ESG and firm value. This finding is consistent with the evidence reported in the extant literature examining the association between ESG and firm value, examples of these studies include: Jo and Harjoto, 2011; Clarkson et al., 2013; Gregory et al., 2014; Plumlee et al., 2015. 
Table 4: The Regression Analysis

\begin{tabular}{|c|c|c|c|c|}
\hline Variables & ROA & Tobin'sq & Tolerance & VIF \\
\hline Constant & $\begin{array}{l}-2.43 \\
-0.35\end{array}$ & $\begin{array}{l}0.25 \\
0.47\end{array}$ & & \\
\hline ESG & $\begin{array}{l}-0.53 \\
0.24\end{array}$ & $\begin{array}{c}0.24^{*} \\
1.81\end{array}$ & 0.760 & 1.31 \\
\hline Growth & $\begin{array}{c}0.13^{* * *} \\
3.63\end{array}$ & $\begin{array}{c}-0.002 \\
-0.80\end{array}$ & 0.950 & 1.05 \\
\hline Leverage & $\begin{array}{l}-0.11^{* *} \\
-2.43\end{array}$ & $\begin{array}{c}-0.004^{*} \\
-1.72\end{array}$ & 0.884 & 1.13 \\
\hline Size & $\begin{array}{l}0.71 \\
1.36\end{array}$ & $\begin{array}{l}-0.23 \\
-0.74\end{array}$ & 0.700 & 1.43 \\
\hline Liquidity & $\begin{array}{c}-0.10^{* * * *} \\
-2.88\end{array}$ & $\begin{array}{c}-0.001 \\
-0.50\end{array}$ & 0.899 & 1.11 \\
\hline No & 130 & 130 & & \\
\hline Adjusted $\mathbf{R}^{2}$ & 0.139 & 0.121 & & \\
\hline F Value & 3.96 & 5.17 & & \\
\hline
\end{tabular}

\section{Discussion and Conclusion}

CSR has been integrated into the business practices of most of international companies listed in countries with developed capital markets, so there is a considerable increase in the numberof studies that have investigated the economic implications of such practices over the past few years. In particular, the associations between CSR practices and firms' financial performancesas well as firm value have been the topic of acontinuing investigationin the literature. On the other hand, there has been a scarceness of such studies in developing countries, including Egypt. The current study investigates the association between ESGas determined by the Egyptian Corporate Responsibility Index (S\&P/EGX ESG Index)and firm performance and firm value measured using return on assets and Tobin'sq, respectively in 2014. Our results indicatethat there is a negative, but insignificant, association between ESG and firm performance. This finding suggests that companies' investments to improve their ESG performance have an adverse effect on its financial performance. Although this finding is an odd result and is not consistent 
with the extant literature linking CSR practices to firm performance, it is in line with the views which argue that firms encounter a trade-off between ESG practices and financial performance, as companies engaging in socially and environmentally responsible activities will incur further costs (McGuire et al., 1988). On the other extreme, the study reported a significant positive relationship between ESG practices and firm value,suggesting that both market and investors reward companies with active ESG agenda. This evidence is in line with evidence from prior literature.

Since the extant literature linking ESG practices and both firm performance and firm value, the current paper contributes to the work in this area where there is a dearth of prior investigations in developing countries, including Egypt. Furthermore, the current study provides recent evidence concerning the economic implications of CSR practices. The data is up-to-date and from a source that has not been investigated in the past. The results of the present study have a number of practical implications for both national (Egypt) and international corporations. Moreover, the evidence reportedin the current study should be of interest to regulators and standard-setters charged with developing standards and guidelines for ESG disclosure in Egypt.

Consistent with the global call for more socially and environmental responsible businesses, more studies are required in this area. First, a useful expansion of this study could focus on examining the factors that influence firms' decisions to engage in CSR practices. Taking into account the value of interested parties' views concerning these practices, a second extension of the current analysis could examine the perceptions of interested parties towards ESG activities undertaken by companies listed on the EGX. A third expansion might involve a cross-country comparative analysis of ESGpractices in the Middle East and North African 
(MENA) region; whilst analyses of prior literature across the broad field of accounting has tended to group MENAnations together, there are many differences in economic, culture and political contexts and international replication of the work could yield important insights. 


\section{References}

Barnea, A., Rubin, R. (2010) Corporate Social Responsibility as a Conflict between Shareholders. Journal of Business Ethics, Vol. 97, No. 1, pp. 71-86.

Bonetti, P., Cho, C. H., Michelon, G. \& Tanaka, Y. (2014) Environmental disclosure and the Cost of Capital: Evidence from the Fukushima Nuclear Accident. Working Paper.

Botosan, C., (1997) Disclosure level and the cost of equity capital. The Accounting Review $72,323-349$.

Botosan, C. (2006) Disclosure and the Cost of Capital: What Do We Know? Accounting and Business Research, Vol. 36, S1, pp. 31-40.

Botosan, C., Plumlee, M. (2005) Assessing Alternative Proxies for the Expected Risk Premium. The Accounting Review 80, 21-53.

Botosan, C., Plumlee, M., Wen, H. (2011) The relation between expected returns, realized returns, and firm risk characteristics. Contemporary Accounting Research 28 (4), 1085-1122.

Clarkson, P.M., X. Fang, Y. Li and G. Richardson. (2013)The relevance of environmental disclosures: are such disclosures incrementally informative? Journal of Accounting and Public Policy,Vol. 32, No. 5, pp. 410-431.

Clarkson, P., Li, Y., Richardson, G., Vasvari, F.(2011) Does it really pay to be green? Determinants and consequences of proactive environmental strategies, Journal of Accounting and Public Policy 30, 122-144.

Clarkson, P., Li, Y., Richardson, G., Vasvari, F. (2008) Revising the relation between environmental performance and environmental disclosure: an empirical analysis. Accounting, Organizations, and Society 33, 303-327.

Clarkson, P., Li, Y., Richardson, G.(2004)The market valuation of environmental expenditures by pulp and paper companies. The Accounting Review 79, 329-353.

Cochran, P. L., Wood, R. A. (1984) Corporate Social Responsibility and Financial Performance. Academy of Management Journal, Vol. 27, No. 1, pp. 181-191.

Coller, M., Yohn, T. (1997) Management forecasts and information asymmetry: an examination of bid-ask spreads. Journal of Accounting Research 35 (2), 181-191.

Collins, D., Maydew, E., Weiss, I. (1997) Changes in the value-relevance of earnings and book value over the past forty years. Journal of Accounting and Economics 24, 39-67.

Connors, E., Silva-Gao, L. (2008)The impact of environmental risk on the cost of equity capital: evidence from the toxic release inventory. Working Paper.

Cormier, D., Magnan, M., Morard, B. (1993)The impact of corporate pollution on market valuation: some empirical evidence. Ecological Economics 8, 135-155.

Cormier, D., Magnan, M. (1997) Investors' assessment of implicit environmental liabilities: an empirical investigation. Journal of Accounting and Public Policy 16, 215-241.

De Franco, G., Hope, O., Larocque, S. (2012)The effect of disclosure on the pay-performance relation. Journal of Accounting and Public Policy.

Dhaliwal, D., Li, O., Tsang, A., Yang, G. (2011) Voluntary non-financial disclosure and the cost of equity capital: The initiation of corporate social responsibility reporting. The Accounting Review 86 (1), 59-100.

Easton, P. (2004) PE ratios, PEG ratios, and estimating the implied expected rate of returns on equity capital. The Accounting Review 79, 73-95.

Fama, E. F. \&MacBeth, J. D. (1973) Risk, return, and equilibrium: Empirical tests. The Journal of Political Economy, 81(3), pp 607-636.

Francis, J., LaFond, R., Olsson, P. \&Schipper, K. (2005) The market pricing of accruals quality. Journal of Accounting and Economics, 39(2), pp 295-327. 
Global Sustainable Investment Alliance (2014), Report on Global Sustainable Investment Review. Available online at: http://www.gsi-alliance.org/wp content/uploads/2015/02/GSIA_Review_download.pdf, accessed on 30/4/2015.

Gode, D. \&Mohanram, P. (2003) Inferring the cost of capital using the Ohlson-Juettner model. Review of Accounting Studies, 8(4), pp 399-431.

Gray, P., Koh, P. S. \& Tong, Y. H. (2009) Accruals quality, information risk and cost of capital: Evidence from Australia. Journal of Business Finance \& Accounting, 36(1-2), pp 51-72.

Gujarati, D. (2003) Basic econometrics, 4th ed., Boston: McGraw-Hill

Hail, L. \&Leuz, C. (2006) International differences in the cost of equity capital: Do legal institutions and securities regulation matter? Journal of Accounting Research, 44(3), pp 485-531.

Hanafi, R. (2006). An exploration of corporate social and environmental disclosure inEgypt and the UK: a comparative study, PhD thesis, Glasgow University, UK.

Hughes, K., (2000)The value relevance of non-financial measures of air pollution in the electric industry. The Accounting Review (April), 209-228.

Hussainey, K, Elsayed, M \& Abdel Razik, M.(2011) 'Factors affecting corporate social responsibility disclosure in Egypt', Corporate Ownership and Control Journal, vol. 8, no. 4, pp. 432-443.

Jo, H., Harjoto, M. A. (2011) Corporate Governance and Firm Value: The Impact of Corporate Social Responsibility. Journal of Business Ethics, Vol, 103, No. 3, pp. 351383.

King, A., Lenox, M. (2001) Does it really pay to be green? An empirical study of firm environmental and financial performance. The Journal of Industrial Ecology 5 (1), 105-116.

Lang, M., Lines, K. V. \&Maffetti, M. (2012) Transparency, Liquidity, and Valuation: International Evidence on When Transparency Matters Most. Journal of Accounting Research, Vol. 50, No. 3, pp. 729-774

Larocque, S., (2013) Analysts' Earnings Forecast Errors and Cost of Equity Capital Estimates. Review of Accounting Studies, 18(1), pp. 135-166.

Marquardt, C., Wiedman, C. (1998) Voluntary disclosure, information asymmetry, and insider selling through secondary equityofferings. Contemporary Accounting Research 15 (4), 505-537.

McGuire, J. B., Sundgren, A. \&Schneeweis, T. (1988) Corporate Social Responsibility and Firm Financial Performance. Academy of Management Journal, Vol, 31, No, 4, pp. 854-872.

McWilliams, A., Siegel, D. (2000) Corporate Social Responsibility and Financial Performance: Correlation or Misspecification? Strategic Management Journal, Vol. 21, No. 5, pp. 603-609.

McWilliams, A., Siegel, D., (2001) Corporate Social Responsibility: A Theory of the Firm Perspective. Academy of Management Review, Vol. 26, No. 1, pp. 117-127.

Mishra, S. B., Suar, D. (2010) Does Corporate Social Responsibility Influence Firm Performance of Indian Companies. Journal of Business Ethics, Vol, 95, No, 4, pp. 571-601.

Newey, W. K. \& West, K. D. (1987) A simple, positive semi-definite, heteroscedasticity and autocorrelation consistent covariance matrix. Journal of the Econometric Society, 55(3), pp 703-708.

Ohlson, J., 1995. Earnings, book values, and dividends in equity valuation. Contemporary Accounting Research (Spring), 661-687. 
Plumlee, M., Brown, D., Hayes, R., Marshall, S. (2010) Voluntary environmental disclosure quality and firm value: Furtherevidence. University of Utah, Working Paper.

Plumlee, M., Brown, D., Hayes, R., Marshall, S. (2015) Voluntary environmental disclosure quality and firm value: Further evidence. Journal of Accounting and Public Policy, 34, pp, 336-361.

Rogers, J., Skinner, D., Van Buskirk, A. (2009) Earnings guidance and market uncertainty. Journal of Accounting and Economics 48(1), 90-109.

Rogers, J., Van Buskirk, A. (2009) Shareholder litigation and changes in disclosure behaviour. Journal of Accounting and Economics47 (1/2), 136-156.

Richardson, A., Welker, M. (2001) Social disclosure, financial disclosure and the cost of equity capital. Accounting, Organizationsand Society 26, 597-616.

Rizk, R., Dixon, R. and Woodhead, A. (2008). 'Corporate social and environmental reporting: a survey of disclosure practices in Egypt', Social ResponsibilityJournal, 4 (3), 306323.

Salama, A. (2005) A note on the impact of environmental performance of financial performance. Structural Change and Economic Dynamics, 15, pp. 413-421.

Salama, A. (2009). 'Egypt: Social responsibility disclosure practices', Idowu, S.O.and Filho, W.L. (eds), Global Practices of Corporate Social Responsibility,Chapter 16, 325-342.

Sharfman, M., Fernando, C. (2008) Environmental Risk Management and the Cost of Capital. Strategic Management Journal 29,569-592.

World Business Council for Sustainable Development and UNEP Finance Initiative (2010) Key insights forcompanies and investors. Report from an international workshop series of the WBCSD and UNEP FI, Translating ESG intosustainable business value.

Wooldridge, J. M. (2010) Econometric analysis of cross section and panel data. Cambridge Massachusetts: The MIT Press. 